\title{
Piotr Sikora
}

Akademia Ignatianum, Kraków

ORCID: 0000-0003-1214-8494

e-mail: piotr.sikora@ignatianum.edu.pl

\section{Sokratejsko-platońska filozoficzna terapia religii Zarys problematyki}

\section{Uwagi wstępne}

Pomysł, by rozważać możliwość filozoficznej terapii religii, opiera się na idei filozofii jako terapii. Ma ona swe źródła w starożytności. Jako troskę o duszę pojmował filozofowanie już Sokrates ${ }^{1}$. Jeszcze bardziej wyraźnie, gdyż używając explicite kategorii zdrowia, łączył filozofowanie z terapią Epikur i porównywał je do sztuki lekarskiej². Do kilkusetletniej tradycji w swoich czasach nawiązywał też Epiktet, gdy twierdził, że „izbą lekarską, mężowie, jest sala wykładowa filozofa” ${ }^{3}$.

1 Por. np. Platon, Laches, przeł. Władysław Witwicki (Warszawa: Wydawnictwo Recto, 1991), 41.

${ }^{2}$ Por. Epikur, Listy oraz wybór świadectw, przeł. Kazimierz Leśniak (Warszawa: Wydawnictwo UKSW, 2015), 76: „Niechaj młodzieniec nie zaniedbuje filozofii, a i starzec niech się nie czuje niezdolny do dalszego jej studiowania. Dla nikogo bowiem nie jest ani za wcześnie, ani za późno zacząć troszczyć się o zdrowie swej duszy"; por też: Porfiriusz z Tyru, List do Marcelli, przeł. Piotr Ashwin-Siejkowski (Kraków: Wydawnictwo WAM, 2006), 63.

3 Epiktet, Diatryby. Encheiridion, przeł. Leon Joachimowicz (Warszawa: PWN, 1961), 299. Literatura dotycząca terapeutycznej roli filozofii, zwłaszcza filozofii starożytnej, ale nie tylko, rozrasta się w ogromnym tempie. Dyskusja na temat rozmaitych koncepcji terapii filozoficznej czy też poradnictwa filozoficznego przekracza ramy niniejszego artykułu. Tu chciałbym zwrócić uwagę na takie pozycje, jak: Konrad Banicki, „Philosophy as Therapy: Towards a Conceptual Model”, Philosophical Papers 43, 1(2014):7-31; Juliusz Domański, Metamorfozy pojęcia filozofii, przeł.Zofia Mroczkowska, 
Wskazany wyżej "terapeutyczny" sposób rozumienia i uprawiania filozofii został w późniejszych wiekach zmarginalizowany. Jak twierdzi Juliusz Domański, stało się to za przyczyną chrześcijańskich myślicieli, którzy uznali, że tylko wiara chrześcijańska jest w stanie uzdrowić ludzką „duszę", a pozbawione łaski pogańskie filozofowanie może co najwyżej przynieść cząstkową wiedzę teoretyczną

Współcześnie ponowne połączenie pojęć filozofii i terapii zawdzięczamy przede wszystkim Ludwigowi Wittgensteinowi. Ściśle rzecz biorąc, pomysł autora Dociekań różnił się jednak znacznie od idei starożytnych. Podczas gdy tamci uważali, że terapii potrzebuje ten, kto nie filozofuje, Wittgenstein wskazywał, iż to filozofowie są pierwszymi kandydatami na pacjentów. Aby zaznaczyć tę różnicę, Eugen Fischer rozróżnił "terapię filozoficzną" i "filozofię terapeutyczną". Łączy je to, że obie posługują się metodami filozoficznymi. Ta pierwsza zajmuje się pozafilozoficznymi problemami realnego życia. Ta druga - ją właśnie zdaniem Fischera uprawiał Wittgenstein - stawia sobie za cel likwidację problemów powstających w procesie refleksji filozoficznej ${ }^{5}$. Filozoficzna terapia religii, o której traktuje niniejszy artykuł, choć czerpie inspiracje z myśli Wittgensteina, sytuuje się po stronie terapii filozoficznej.

W swoich rozważaniach zgadzam się z Fischerem co do tego, że filozofia może być uznana za - literalnie - terapię po pierwsze ze względu na cel, jaki podejmuje uprawiający ją filozof, tj. gdy celem jego filozofowania jest rozwiązanie emocjonalnych i behawioralnych problemów trapiących ludzi i pomoc w osiągnięciu przez nich zdrowia mentalnego ${ }^{6}$. Zdaniem Fischera sam proces terapii filozoficznej jest bardzo podobny do tego, co dzieje się w psychoterapii poznawczej, a szczególny wkład filozoficzny polega na wykorzystywaniu rezultatów etyczno-filozoficznego namysłu nad tym, co czyni człowieka i jego życie wartościowym7

Mirosław Bujko (Warszawa: Wydawnictwo IFiS PAN, 1996); Eugen Fischer, Linguistic creativity. Exercises in "Philosophical Therapy" (Dordrecht-New York-London: Kluwer Academic Publishers, 2011); Pierre Hadot, Czym jest filozofia starożytna, przeł. Piotr Domański (Warszawa: Aletheia, 2000); Pierre Hadot, Filozofia jako ćwiczenie duchowe, przeł. Piotr Domański (Warszawa: Aletheia, 2003); Lou Marinoff, Philosophical Practice (Sane Diego: Academic Press, 2002); Martha Nussbaum, The Therapy of Desire. Theory and Practice in Hellenistic Ethics (Princeton, New Jersey: Princeton University Press, 1994); Krzysztof Pawłowski, Dyskurs i asceza (Kraków: Wydawnictwo Benedyktynów Tyniec, 2007); James F. Peterman, Philosophy as therapy: an interpretation and defense of Wittgenstein's later philosophical project (New York: State University of New York Press, 1992); Donald Robertson, The Philosophy of Cognitive-Behavioural Therapy. Stoic Philosophy as Rational and Cognitive Psychotherapy (London: Karnac, 2010).

4 Por. Domański, Metamorfozy pojęcia filozofii, 19--24.

5 Por. Eugen Fischer, "How to Practice Philosophy as Therapy: Philosophical Therapy and Therapeutic Philosophy", Metaphilosophy 42, 1-2 (2011), 49-82.

6 Por. tamże, 49-51.

7 Por. tamże, 57. 
Inspiruję się także bardziej rozbudowanym modelem filozofii jako terapii (terapii filozoficznej w nomenklaturze Fischera), jaki zaproponowała Martha Nussbaum ${ }^{8}$. Nussbaum chodzi o filozofowanie, którego podstawowym motywem jest problem ludzkiego cierpienia, a celem doprowadzenie człowieka do "rozkwitu”, eudaimonii. Aby działanie o takim motywie i celu mogło być nazwane filozofią, musi „używać argumentów, precyzyjnych definicji i całego rygoru myślenia"”. By filozoficzne myślenie było terapeutyczne, musi posiadać co najmniej trzy cechy: (1) argumenty muszą mieć cel praktyczny - czynić ucznia lepszym; (2) muszą być one powiązane $\mathrm{z}$ wartościami, odpowiadać na głębokie pragnienia i potrzeby człowieka, (3) rozumowanie filozoficzne musi być reakcją na konkretną sytuację ${ }^{10}$.

Moje rozumienie filozofii jako terapii bliskie jest też modelowi, który na polskim gruncie zaproponował Konrad Banicki ${ }^{11}$. Model ten jest o tyle ciekawy, że jest próbą systematyzacji intuicji pojawiających się w bogatej współczesnej literaturze przedmiotu. Zgodnie z propozycją Banickiego, by daną filozofię można było uznać za terapię, musi mieć w niej zastosowanie siedem pojęć: „(1) choroba i jej symptomy, (2) ideał zdrowia, (3) proces leczenia wraz z właściwymi mu technikami, (4) stojąca u podstaw terapii teoria, (5) lekarz, (6) pacjent, a także (7) relacja terapeutyczna"12. Zdaniem Banickiego kluczowe jest tu pojęcie choroby, które być może zbudowane jedynie na tle ideału zdrowia.

Podsumowując tę część rozważań, chciałbym dookreślić, że przez terapię filozoficzną rozumiem proces filozofowania, którego (1) punktem wyjścia jest rozpoznanie, iż egzystencja poszczególnego człowieka lub grupa ludzi może być określona jako trapiona choroba, tj. rodząca cierpienie; (2) celem jest zaradzenie tej sytuacji, tj. zmniejszenie cierpienia i pomoc w pełniejszym ludzkim rozwoju; (3) powyższy cel osiagany jest metodami filozoficznymi: stawianiem pytań, precyzowaniem pojęć, analizą spójności przekonań, formułowaniem argumentów itp.; (4) w procesie terapii wykorzystywane są filozoficzne koncepcje dotyczące ludzkiego rozwoju i dobrego życia.

Sformułowanie "filozoficzna terapia religii" pozostaje o tyle wieloznaczne, o ile wieloznaczny jest użyty tu termin „religia”. Przez religię

8 Nussbaum, The Therapy of Desire. Theory and Practice in Hellenistic Ethics.

9 Tamże, 15.

10 Tamże, 46. Nussbaum wymienia jeszcze sześć niekoniecznych cech terapeutycznego dyskursu filozoficznego. Dyskusję nad nimi tutaj pominę.

11 Por. Banicki, „Philosophy as Therapy: Towards a Conceptual Model”; tenże, „Medyczny model filozofii, czyli między starożytną terapią a współczesną psychologią emocji" [w:] Therapeia, askesis, meditatio: praktyczny wymiar filozofii o starożytności i średniowieczu, red. Krzysztof Łapiński i in. (Warszawa: Wydawnictwo UW, 2017).

12 Banicki, „Medyczny model filozofii, czyli między starożytną terapią a współczesną psychologią emocji", 308. 
można bowiem rozumieć pewne uniwersum symboliczne (zespół symboli, doktryn, wskazówek, norm, narracji itp.). Można rozumieć ją jako pewną historyczną tradycję. Można też jednak postrzegać religię przede wszystkim od strony podmiotów posługujących się owymi symbolami i prowadzącymi pewien sposób życia (dokonującymi aktów religijnych $)^{13}$. W dalszej części artykułu przyjmuję tę ostatnią perspektywę. Terapia bowiem zaczyna się od sytuacji, w której ktoś cierpi i najczęściej skarży się („,cierpię, bo...”). Cierpieć i skarżyć się na cierpienie może konkretny człowiek. Związek terapii i religii nawiązuje się zaś w sytuacji, gdy w (wypowiedzianej bądź niewypowiedzianej) skardze człowieka pojawia się treść, którą można by podsumować w stwierdzeniu: „cierpię z powodu religii".

$\mathrm{W}$ procesie ewentualnej filozoficznej terapii religii $\mathrm{w}$ centrum musi znajdować się konkretny (cierpiący) człowiek. Może być tak, że (1) raniąca, tj. powodująca cierpienie, jest religia rozumiana jako cała tradycja religijna i/lub pewne uniwersum symboliczne albo nawet pewna wspólnota religijna, do której skarżący się człowiek należy - poprzez wpływ, jaki wywiera ona na człowieka. W takim przypadku filozoficzna terapia religii musiałaby być próbą zmiany danej tradycji/wspólnoty religijnej/ religijnego uniwersum symbolicznego środkami filozoficznymi, tak by rzeczywistości te nie powodowały cierpienia. Może jednak być tak, że to (2) indywidualna religijność (religijny sposób życia) danego człowieka jest przyczyną jego cierpienia - wówczas filozoficzna terapia religii staje się filozoficzną terapią religijności danego człowieka.

Oczywiście przypadki (1) i (2) są najczęściej powiązane. Tak więc to rozróżnienie raczej heurystyczne; w rzeczywistości chodzi raczej o punkt ciężkości ewentualnego terapeutycznego procesu.

\section{Kwestia możliwości filozoficznej terapii religii}

Tu jednak pojawia się pytanie, czy tak rozumiana filozoficzna terapia religii jest $\mathrm{w}$ ogóle możliwa, tj. czy filozofia ma odpowiednie kompetencje, by dokonać diagnozy, tj. rozpoznać, czy to rzeczywiście religia, na którą człowiek się skarży, jest źródłem cierpienia, oraz czy posiada kompetencje i środki do przeprowadzenia skutecznej terapii. Powyższe wątpliwości rodzą się w wyniku dwóch rodzajów argumentacji.

13 Por. Jan Andrzej Kłoczowski, Między samotnościa a wspólnota (Tarnów: Biblos, 2004), 95. 
Pierwszy rodzaj argumentacji nie odwołuje się w ogóle do kategorii religijnych. Rozumowanie wychodzi tu od twierdzenia, że filozofia i religia to dwie różne formy życia/gry językowe/układy pojęciowe ${ }^{14}$. Następnym krokiem jest wskazanie, że nie można rozumieć ani tym bardziej oceniać zasad jednej gry (i posunięć w jej ramach) wedle reguł innej gry. Każda forma życia ma zatem sobie właściwe kryteria sensu, racjonalności czy poprawności przekonań i działań. Klasyczne sformułowanie tego argumentu można znaleźć w Wittgensteina „Wykładach o wierze”, gdzie wskazywał on swoim słuchaczom na ograniczenia możliwości filozoficznej krytyki religii, zwłaszcza tam, gdzie perspektywa ludzi religijnych różni się radykalnie od „rozumnej” perspektywy filozofa. W takiej sytuacji próba uznania zachowań ludzi religijnych za błędne sama okazuje się błędem, gdyż ,jeśli coś jest lub nie jest błędem, to jest błędem $\mathrm{w}$ ramach danego systemu. Tak jak coś jest błędem $\mathrm{w}$ danej grze, a nie w innej"15, a więc coś, co wygląda na błąd z perspektywy filozofii, wcale nie musi być błędem $\mathrm{w}$ religii.

Powyższy argument był rozwijany przez uczniów Wittgensteina ${ }^{16}$. Tak np. Peter Winch w swoim słynnym dziele Idea nauki o społeczeństwie i jej zwiazki z filozofia przekonuje, że nawet „kryteria logiki to nie dar pochodzący wprost od Boga, lecz [...] wyłania je cała sieć trybów i sposobów życia społecznego i tylko w tym kontekście są one zrozumiałe", a więc zarówno nauka, jak i religia „ma swoiste kryteria sensowności”"17. W konsekwencji właściwe kryteria pozwalające odpowiednio klasyfikować, a tym bardziej oceniać dane czynności religijne „należą do samej religii"18. Uzurpacją jest więc próba zewnętrznej oceny zasadności bądź absurdalności konkretnych przekonań czy działań człowieka religijnego, nawet jeśli z niereligijnej perspektywy wyglądają na w oczywisty sposób nieracjonalne ${ }^{19}$.

${ }^{14}$ Dla potrzeb niniejszego artykułu uznaję, że desygnaty tych trzech nazw są na tyle powiązane, że wspomniane nazwy można w większości kontekstów stosować zamiennie.

${ }^{15}$ Ludwig Wittgenstein, „Wykłady o wierze”, przeł. Wojciech Sady, w: Ludwig Wittgenstein, Uwagi o religii i etyce (Kraków: SIW Znak, 1995), 92-93.

16 Skupionych głównie w tzw. szkole ze Swansea. Na ten temat patrz: Jakub Gomułka, Gramatyka wiary. Dziedzictwo wittgensteinowskiego fideizmu (Kraków: Instytut Myśli Józefa Tischnera, 2011).

${ }_{17}$ Peter Winch, Idea nauki o społeczeństwie $i$ jej zwiazki z filozofia, przeł. Bohdan Chwedeńczuk (Warszawa: Oficyna Naukowa, 1995), 104.

18 Por. tamże, 91.

19 Por. też Peter Winch, „Rozumienie społeczeństwa pierwotnego”, przeł. Tadeusz Szawiel, w: Racjonalność i styl myślenia, red. Edward Mokrzycki (Warszawa: Wydawnictwo IFiS PAN, 1992). 
Argumentację Wincha można wzmocnić, uwzględniając obserwacje innego przedstawiciela szkoły ze Swansea, Dewiego Z. Phillipsa, który zauważa, że człowiek religijny posiada sobie właściwe, religijne kryteria oceny rzeczywistości i swego życia: „,skoro dla wielu wierzących miłość Boga określa to, co należy uważać za ważne, pojawią się sytuacje, w których to, co wierzący nazwie sukcesem, będzie niepowodzeniem w oczach świata [...], to, co nazwie on zwycięstwem, będzie uchodziło za całkowitą klęskę"20.

Tak więc w zarysowanej wyżej perspektywie filozof jako ktoś grający w inną grę niż człowiek religijny ulega złudzeniu, myśląc, że rozumie skargę tamtego, i wykazuje się opartą na ignorancji arogancja, gdy sądzi, że zna odpowiednie metody pozwalające skutecznie "wyleczyć" to, co jawi mu się jako ludzkie cierpienie. Nie zna bowiem ani jego prawdziwej natury, ani jego przyczyn, nie wie też, jaki stan człowiek religijny uznałby za "stan zdrowia".

Argumenty powyższe są o tyle istotne, że wymienieni wyżej filozofowie rozwijający wizję filozofii jako terapii (Nussbaum, Fischer, Banicki) wskazuja iż właśnie filozoficzna koncepcja, czym jest ów „stan zdrowia", czyli ludzkiego rozkwitu, stanowi szczególny wkład filozofii w proces terapeutyczny. Choć bowiem warunkiem sine qua non, by proces taki miał charakter filozoficzny, jest jego racjonalny charakter, to trudno odróżnić filozoficzny sposób postępowania terapeutycznego od metod stosowanych w psychoterapii poznawczej. Miejsce, gdzie filozofia może wnieść swój istotny, specyficzny wkład w proces terapii, można odnaleźć właśnie tu, jak pisze Fischer: „badanie i ocena, egzystencjalnych założeń, co czyni ludzi wartościowymi, a życie godnym, znajduje się w centrum zainteresowania filozoficznej etyki" ${ }^{\prime 21}$. Gdyby więc było prawda, że filozofia nie posiada kompetencji do wypowiadania się na temat religijnego ideału życia, filozoficzna terapia religii nie byłaby możliwa. Biorąc zaś pod uwagę powyższe i podobne im argumenty, łatwo o przekonanie, że wątpliwość, czy filozof - jako filozof - posiada kompetencje do zrozumienia i oceny religijnej formy życia, które pozwoliłyby mu przeprowadzić filozoficzną terapię religii, nie jest pozbawiona racjonalnych podstaw.

${ }^{20}$ Dewi Z. Phillips, „Wiara religijna a gry językowe, przeł. Michał Szczubiałka, w: Filozofia religii. Fragmenty filozofii analitycznej, red. Bohdan Chwedeńczuk (Warszawa: Spacja - Aletheia, 1997), 299-322, 304. Bardziej szczegółową argumentację korzystającą z uwag Wittgensteina, a także filozoficznych pomysłów Hilarego Putnama można znaleźć w: Piotr Sikora, Stowa i zbawienie. Dyskurs religijny w perspektywie filozofii Hilarego Putnama (Kraków: Universitas, 2004), 191-199, 215-222.

21 Por. Fischer, „How to Practice Philosophy as Therapy: Philosophical Therapy and Therapeutic Philosophy", 57 
Wątpliwości, czy możliwa jest filozoficzna terapia religii, wzmacnia również argumentacja odwołująca się wprost do kategorii religijnych (dlatego nazwijmy ją teologiczną). Wskazuje ona, że filozofia jest aktywnością ludzkiego rozumu, religia zaś ma źródła objawione, boskie. Człowiek jednak - brzmi kluczowy argument - nie ma kompetencji, by sądzić Boga. Jeśli więc nawet z punktu widzenia skarżącego się człowieka to religia jest przyczyną jego cierpienia, filozof słyszący tę skargę nie może ze swojego filozoficznego, a więc ludzkiego, punktu widzenia adekwatnie ocenić wartości tego cierpienia ani tym bardziej uzurpować sobie prawa do stymulowania jakichś zmian - ani w tradycji religijnej, której uczestnikiem jest skarżąca się osoba, ani w indywidualnej religijności tej osoby. W europejskiej kulturze klasycznym przykładem takiej sytuacji jest historia ofiarowania Izaaka przez Abrahama (por. Rdz 22, 1-19). Usłyszany przez Abrahama Boży nakaz z pewnością powodował cierpienie. Z punktu widzenia refleksji filozoficznej było to nie tylko polecenie nieetyczne, ale przejaw dysfunkcyjnej religijności wymagającej terapii. Jednak z punktu widzenia człowieka religijnego wszelkie czysto ludzkie oceny musiały ustąpić przed absolutną zobowiązywalnością boskiego głosu. Jak pokazuje koniec biblijnej historii, to właśnie posłuszeństwo owemu głosowi, wbrew rozumowi i intuicjom moralnym, miało przynieść pozytywne skutki.

Łatwo oczywiście zauważyć, że zarysowana powyżej argumentacja teologiczna posiada moc przekonywania jedynie przy założeniu, że religia (religia w ogóle bądź też konkretna, dana religia) rzeczywiście jest wyrazem boskiego objawienia. Filozof może tego założenia nie podzielać. Niemniej jednak konkluzywne rozstrzygnięcie, kto w tej kwestii ma rację, jest niezwykle trudne, jeśli w ogóle możliwe. W dalszej więc części swojego tekstu poszukuję zatem innego rozwiązania - bronię możliwości filozoficznej terapii religii nawet przy założeniu prawdziwości podstawowej przesłanki argumentacji teologicznej, tj. przy uznaniu boskiego pochodzenia religii.

\section{Ad. I}

Zacznijmy jednak od pierwszej trudności, która głosi, że filozofia i religia to różne gry językowe, a posunięć dokonywanych w jednej grze nie sposób oceniać i modyfikować za pomocą reguł obowiązujących w innej grze.

Przy rozważaniu zasadności tego argumentu powinno zastanowić już to, że zarówno Wittgenstein, jak i jego uczniowie (np. Phillips), podkreślając niewspółmierność religijnej formy życia i religijnego dyskursu z niereligijnymi odpowiednikami, jednocześnie jako filozofowie, 
tj. w swoich filozoficznych rozważaniach, dokonują rozróżnienia na autentyczną religijność i przesądy ${ }^{22}$. Ten akt rozróżnienia jest wszak możliwy tylko wówczas, gdy rozróżniający wie, jaki jest zasadniczy cel (point) religijnej formy życia i kiedy forma ta przybiera właściwa a kiedy zdegenerowaną postać. Sposób prowadzenia filozoficznej argumentacji mającej na celu przeprowadzenie rozróżnienia na autentyczną religijność i przesądy wskazuje, że nie ma ona charakteru zewnętrznego wobec religijnej formy życia ${ }^{23}$.

Powyższy fakt sugeruje, że warto rozważyć możliwość, iż potraktowanie filozofii i religii jako odseparowanych od siebie gier było zbyt pochopne. Analizując ja, warto zwrócić uwagę, że wspominany wyżej Peter Winch sam ostrzega przed zbytnią separacją poszczególnych form życia, gdyż „różne przejawy życia społecznego nakładają się na siebie, można mieć na przykład religijne powody, by poświęcić się nauce"24. Wiele lat później, po licznych debatach, Winch przyznał nawet, że „różne przejawy życia społecznego nie tylko »nakładają się na siebie«: często są one ze sobą powiązane wewnętrznie $\mathrm{w}$ taki sposób, że nie można pomyśleć z sensem, że istnieją w oderwaniu od siebie" 25 .

Samo wskazanie na wzajemne powiązania rozmaitych przejawów życia społecznego nie wystarczy jednak do rozwiania wątpliwości, czy filozofia posiada kompetencje do prowadzenia terapii religii. Podobnie sam fakt, że religia czerpie swe znaczenie z tego, iż „ma coś do powiedzenia o takich aspektach ludzkiej egzystencji, które są całkiem zrozumiałe bez odniesienia do religii" 26 , nie znaczy, że filozofia ma coś istotnego do powiedzenia o religijnych wierzeniach i działaniach. Ostrzeżenia Wittgensteina przed pokusą zbyt szybkiej uniwersalizacji kryteriów poprawności wypracowanych $\mathrm{w}$ ramach jakieś jednej gry językowej nie zostają unieważnione po prostu przez obserwację, że gry językowe nie są całkowicie od siebie odseparowane.

W tym miejscu trzeba odpowiedzieć na pytanie: na jakiej zasadzie różnicować gry językowe/układy pojęciowe? Tutaj przyjmuję rozwiązanie idące po linii myśli Hilarego Putnama, zgodnie z którym podstawową zasadą różnicującą układy pojęciowe jest określona potrzeba czy też „interes” (poznawczy bądź poza poznawczy), któremu służy stosowanie danego układu. W języku Wittgensteina można też powiedzieć, że o tożsamości gry stanowi cel, ku któremu zmierza. W kontekście

${ }^{22}$ Por. Wittgenstein, Wykłady o wierze, 93; Philips, „Wiara religijna a gry językowe", 318n.

${ }^{23}$ Por. np. Phillips, „Wiara religijna a gry językowe”.

${ }^{24}$ Por. Winch, Idea nauki o społeczeństwie i jej związki z filozofia, 104.

25 Tamże, 9-10.

26 Phillips, „Wiara religijna a gry językowe”, 317. 
zasadniczego problemu niniejszego tekstu istotne jest zatem to, jakie są owe potrzeby i cele religijnych i filozoficznych gier językowych ${ }^{27}$.

Już pobieżny rzut oka na historię kultury ujawnia rozmaitość zjawisk, które były i są nazywane religia, oraz wielość i różnorodność prób sformułowania definicji religii (która to definicja miałaby ująć jakąś istotę tej rozmaitości zjawisk). Porównajmy ze sobą choćby skupiony na milczącej, siedzącej medytacji buddyzm zen, kładące nacisk na lekturę Biblii i etyczne życie purytańskie odłamy protestantyzmu oraz rytualistyczno-panteistyczne kulty niektórych plemion amazońskich - jak wiele tu oczywistych różnic! Podobna sytuacja ma miejsce $\mathrm{w}$ odniesieniu do definicji religii. Weźmy choćby dwie, pochodzące ze starożytności. Cycero pisze: „Ci, którzy pilnie rozważyli i ponownie jak gdyby zebrali (relegerent) to, co dotyczy kultu bogów, nazwani są religijnymi" 28 . Chrześcijanin Laktancjusz ujmuje rzecz inaczej: „Tym węzłem pobożności połączeni jesteśmy i jakby związani z Bogiem, skąd i religia bierze swą nazwę"29. Zauważmy, że o ile pierwsza jako istotną cechę religii wymienia relekturę - znajomość i kontynuowanie tradycji kultu bogów, a więc pewnego publicznego, rytualnego zachowania, to dla drugiej istotą religii jest osobista więź z Bogiem - tu kwestia publicznej tradycji praktycznie się nie pojawia. Ze względu zatem na taką różnorodność (wyżej zaledwie zarysowaną), rozsądnie jest przyjąć, iż termin „religia” jest słowem o „rodzinowym” znaczeniu, w dodatku zmieniającym się w historii. Nasze dzisiejsze użycie tego terminu pozostaje pod wpływem historii jego używania.

W naszym współczesnym, polskim kontekście kulturowym „wzorcową" religia, do której najczęściej stosujemy ów termin i która stanowi najczęstszy punkt porównania innych zjawisk, które jesteśmy skłonni określić tym terminem, jest chrześcijaństwo (i to w wydaniu katolicki$\mathrm{m})^{30}$. W tym kontekście można stwierdzić, że celem religijnej formy życia jest coś, co w języku chrześcijańskim nazywa się zbawieniem, a co można też określić jako ostateczne spełnienie ludzkiej egzystencji obejmujące rozkwit wszelkich potencjalności człowieka (jako osoby i wspólnoty) i zjednoczenie z absolutnym fundamentem rzeczywistości, nazywanym Bogiem ${ }^{31}$.

27 Szczegółowe uzasadnienie tej odpowiedzi wykracza poza ramy niniejszego artykułu. Zainteresowanych dyskusją odsyłam do: Sikora, Słowa i zbawienie. Dyskurs religijny w perspektywie filozofii Hilarego Putnama, 123-148.

${ }_{28}$ Cyt. za: Kłoczowski, Między samotnościa a wspólnota, 20.

29 Tamże.

30 Zaznaczam, że jest to uwaga czysto semantyczna. Nie wypowiadam się tu w ogóle na temat tego, czy chrześcijaństwo jest w jakimkolwiek sensie „lepsze" od innych religii.

${ }^{31} \mathrm{Na}$ ten temat szerzej por. np. Sikora, Stowa i zbawienie. Dyskurs religijny w perspektywie filozofii Hilarego Putnama, 239-244, 260-262. 
W przypadku filozofii sprawa ma się podobnie $\mathrm{w}$ tym sensie, że w historii napotykamy różnorodność zjawisk/aktywności nazywanych filozofią i trudności w znalezieniu jednej, powszechnie przyjętej jej definicji. Jest raczej tak, iż termin "filozofia" ma znaczenie "rodzinowe". W wielości sposobów filozofowania można zaś odnaleźć nurty i szkoły, które rozwijają się jako realizacja podobnej potrzeby i posiadają podobny cel co religie takie jak chrześcijaństwo. Weźmy choćby Platońską wizję zawartą w Uczcie. Za "mityczny" wzorzec filozofa zostaje tam uznany Eros $^{32}$ - i to właśnie z tego względu, że łączy sprawy ludzkie z boskimi. Eros „tłumaczy i przekazuje bogom rzeczy od ludzi, a ludziom rzeczy od bogów. [...] Będąc pomiędzy nimi, wypełnia tę przestrzeń, tak że wszystko jest nim zespolone" ${ }^{\prime 33}$. Uważnemu czytelnikowi nie umknie zaś, że Sokrates - ten spośród ludzi, któremu zdaniem autora Uczty najbardziej przysługuje miano filozofa - jest portretowany w tym dialogu właśnie na wzór Erosa ${ }^{34}$.

Bezpośrednia i zarazem zbawcza wizja absolutu o boskich właściwościach jest przedstawiona jako cel filozofowania w drugim „erotycznym" dialogu Platona - Fajdrosie. Wizja ta jest tam ukazana jako najwyższy cel egzystencji, którego niezrealizowanie skazuje duszę na pobyt w otaczającej nas, niedoskonałej empirycznej rzeczywistości. Droga powrotu do doskonałości duszy jest możliwa, lecz ,jedynie umysł miłośnika mądrości [filo-sophos] otrzymuje skrzydła" potrzebne do powtórnego wzlotu ku boskości ${ }^{35}$.

Zmierzanie ku wizji ostatecznej rzeczywistości jest nieodłącznie związane $\mathrm{z}$ transformacją podmiotu. W Uczcie Eros jest utożsamiony $\mathrm{z}$ "pragnieniem poczęcia i zrodzenia [siebie - przyp. P.S.] w pięknie” ${ }^{\prime 36}$. W Fajdrosie Sokrates unika odpowiedzi na pytanie tytułowego bohatera o prawdziwość mitycznych opowieści, a może raczej o to, czy należy je interpretować dosłownie, czy raczej dokonywać racjonalistycznej ich redukcji ${ }^{37}$. Stwierdza: „Ja zaś na te sprawy nie mam wcale czasu. A przyczyną tego, drogi przyjacielu, jest to, że jak dotąd nie mogę - zgodnie z zawołaniem delfickim - poznać samego siebie. Głupio mi się zaiste wydaje, nie znając jeszcze tego, badać rzeczy obce"38. Zauważmy, że Sokrates, który w całym dialogu występuje jako filozof par excellence, powołuje się na napis widniejący na frontonie świątyni w Delfach i traktowany jako pozdrowienie - i wezwanie - boga Apolla skierowane do

32 Platon, Uczta, przeł. Andrzej Serafin (Warszawa: Sic, 2012), 54.

33 Tamże, 53.

${ }^{34}$ Por. Hadot, Czym jest filozofia starożytna, 71nn.

35 Platon, Fajdros, przeł.Leopold Regner (Warszawa: Wydawnictwo Naukowe PWN), 33.

36 Platon, Uczta, 57.

37 Por. Platon, Fajdros, 7.

38 Tamże. 
pielgrzymów przybywających do Wyroczni ${ }^{39}$. Wskazuje tym samym na zbieżność zasadniczego przedmiotu zainteresowania filozoficznych poszukiwań i religijnego dążenia, którym jest samopoznanie. $Z$ dalszej części wypowiedzi filozofa wynika, że samopoznanie jest kluczowym elementem szerszego procesu kształtowania duszy. Filozof robi to w odniesieniu do samego siebie i wobec innych ${ }^{40}$.

Taka idea filozofii kontynuowana była w wiekach późniejszych. W jednym z ważniejszych tekstów średnioplatońskich, Didaskalikosie Alkinousa możemy przeczytać odnośnie o filozofii jako o „upodobnieniu się do boskości"41. Za kulminację zaś egzystencjalno-mistycznego sposobu uprawiania filozofii można uznać działalność Plotyna i jego neoplatońskich uczniów, np. Porfirusza z Tyru ${ }^{42}$.

\section{Ad. II}

Przedstawiony wyżej proces filozofowania, tj. zmierzania ku absolutnej rzeczywistości, nie jest - tak przynajmniej pisze Platon - aktywnością czysto ludzką. Druga mowa Sokratesa w Fajdrosie, w której rysuje on prawdziwą naturę Erosa i filozofii, zostaje wygłoszona z nieodpartego natchnienia dajmoniona o boskich charakterze: „zaczął się odzywać pochodzący od bóstwa - mówi Sokrates Fajdrosowi - zwykły u mnie zna$\mathrm{k}^{\prime \prime 43}$. Ów głos jest na tyle częsty w życiu Sokratesa i tak często filozof się na niego powołuje, że nawet dla niezbyt lotnego Eutyfrona jest to oczywista przyczyna oskarżenia, które doprowadziło Sokratesa do śmierci: „To dlatego, że ty mówisz, że duch do ciebie przychodzi"44.

${ }^{39}$ Por. Krzysztof Bielawski, Delficki trójnóg. Sentencje delfickie (Kraków: Wydawnictwo UJ. Lemma Press, 2017).

${ }^{40}$ Por. Platon, Fajdros, 8; Platon, Laches, przeł. Władysław Witwicki (Warszawa: Wydawnictwo Recto), 41.

${ }_{41}$ Por. Alkinous, Wykład nauk Platona (Didaskalikos), przeł. Kazimierz Pawłowski (Kraków: Wydawnictwo WAM, 2008), 143. O egzystencjalno-mistycznym aspekcie średniego platonizmu - por. Kazimierz Pawłowski, Misteria i filozofia. Misteryjne oblicze filozofii greckiej (Lublin: Towarzystwo Naukowe KUL, 2007), 51-123.

${ }_{42}$ Moim zdaniem w przypadku Plotyna nie ma sensu poszukiwać i wybierać pojedynczych cytatów z Ennead. Dobre, syntetyczne opracowanie tego aspektu myśli twórcy neoplatonizmu znajdziemy w: Pierre Hadot, Plotyn albo prostota spojrzenia, przeł. Patrycja Bobowska (Kęty: Antyk, 2004). Więcej na temat egzystencjalno-mistycznego charakteru starożytnej filozofii greckiej - patrz: Pawłowski, Misteria i filozofia. Misteryjne oblicze filozofii greckiej; Hadot, Filozofia jako ćwiczenie duchowe. Syntetyczną wizję filozoficznej mistyki przedstawia też Karl Albert, Wprowadzenie do filozoficznej mistyki, przeł. Józef Marzęcki (Kęty: Antyk, 2002).

${ }^{43}$ Platon, Fajdros, 24.

44 Platon, Eutyfron, przeł. Józef Bocheński (Warszawa: Fundacja Augusta hr. Cieszkowskiego, 2015), 17. „Duch”, tj. dajmonion - głos ze sfery boskiej. 
Owo ponadludzkie, boskie źródło filozoficznego poznania było kluczowe dla samego Platona, co wyraźnie wynika z słynnego fragmentu Listu VII, w którym pisze on o najważniejszym „rdzeniu” swej filozofii: „Nie są to bowiem rzeczy dające się ująć w słowa, tak jak wiadomości $\mathrm{z}$ zakresu innych nauk, ale z długotrwałego obcowania z przedmiotem, na mocy zżycia się z nim, nagle, jakby pod wpływem przebiegającej iskry, zapala się w duszy światło i płonie, już odtąd samo siebie podsycając" 45 .

Platońską wizję kontynuowali uczniowie założyciela Akademii w późniejszym okresie jej trwania, zwłaszcza w średnim platonizmie. Jeszcze wyraźniejsza stała się ona u Plotyna i jego uczniów, np. Porfiriusza z Tyru.

Gdy przejdziemy do współczesności, warto odnotować nie tylko fakt, że Wittgenstein, choć nie przyznawał się do uczestnictwa w żadnej tradycji religijnej, najprawdopodobniej był człowiekiem, któremu nie obce były głębokie doświadczenia religijne ${ }^{46}$. Związek filozofowania z religijnym wymiarem życia jest równie wyraźny w przypadku uczniów Wittgensteina, takich jak Dewi Z. Phillips czy Rush Rhees, którzy pozostawali pod wpływem filozofki i mistyczki - Simone Weil ${ }^{47}$.

Uczestnicy wielu tradycji religijnych (np. niektórych gałęzi chrześcijaństwa) byliby zapewne skłonni podnieść w tym miejscu zarzut, że owe ",boskie" źródła filozofii to co najwyżej osobiste, a więc subiektywne doświadczenie mistyczne, którego nie można zrównywać z obiektywnym objawieniem Boga przekazywanym przez ich tradycję religijną - a więc, że zarzut „bluźnierczej uzurpacji” filozoficznej terapii religii pozostaje w mocy. Nie sposób w ramach jednego artykułu odnieść się wyczerpująco do wszystkich aspektów tego kontrargumentu. Dla potrzeb mojego rozumowania wystarczy jednak zaznaczyć, że (1) wszelkie teksty, które religie uznają za objawione, zostały napisane przez ludzi, a pretendują do posiadania objawionego charakteru ze względu na to, że ich autorzy powoływali się na „natchnienie”, które - przynajmniej na pierwszy rzut oka - nie posiada radykalnie innego charakteru od tego, na które powoływał się Sokrates bądź Platon; (2) kwestia, czy istnieje taka radykalna różnica, wymaga dopiero zbadania, (3) przeprowadzenie takiego badania wymaga zaangażowania środków, które - jak pokażę niżej - filozof

45 Platon, Listy, przeł. Maria Maykowska (Warszawa: Wydawnictwo Naukowe PWN, 1987).

${ }^{46}$ Por. Fania Pascal, „Wittgenstein: A Personal Memoir”, w: Recollections of Wittgenstein, red. Rush Rhees (Oxford-New York: Oxford University Press, 1984), 44n.; Bertrand Russell, Letters to Russell, Keynes, and Moore, red. Georg H. von Wright (Ithaca, New York: Cornell University Press, 1974), 82; Wojciech Sady, „Wprowadzenie”, w: Wittgenstein, Uwagi o religii i etyce, 7-57.

47 Por. Gomułka, Gramatyka wiary. Dziedzictwo wittgensteinowskiego fideizmu, 108128. 
taki jak Sokrates stosował w rozmowie z człowiekiem religijnym o religii, czyli w konsekwencji badanie to może być elementem procesu, który nazywam filozoficzną terapią religii.

\section{Filozoficzna terapia religii - proces}

Przeciwko stwierdzeniu, że filozoficzną terapię religii można prowadzić w oparciu o sokratejsko-platońską wizję filozofii, można wysunąć zarzut, iż - jak argumentowała Martha Nussbaum - fundamentalne założenia platonizmu przeszkadzają w prowadzeniu dobrej filozoficznej terapii ${ }^{48}$. Argumentację Nussbaum uważam za błędna, gdyż opartą na jednostronnej interpretacji tradycji platońskiej. Nie sposób w krótkim artykule podjąć kompleksowej dyskusji na temat platonizmu. Zamiast tego chcę przedstawić - jako kontrprzykład wobec tezy Nussbaum szkic, jak taka sokratejsko-platońska terapia religii może wyglądać - inspirację, czerpiąc z jednego z platońskich dialogów - Eutyfrona ${ }^{49}$.

Tytułowym bohaterem tego dialogu jest młody wróżbita, który nie może uzyskać szerszego uznania, lecz jest wyśmiewany przez ateński ogół. Radzi sobie ze społecznym odrzuceniem poprzez pogardę dla tłumu i niemal narcystyczne przekonanie o własnej mądrości i znajomości rzeczy boskich. Sokrates spotyka go, gdy Eutyfron znajduje się w sytuacji rodzinnego konfliktu - chce wnieść oskarżenie przeciw własnemu ojcu o morderstwo (w sytuacji, gdy rodzic odpowiedzialny jest raczej za zaniedbanie, które doprowadziło do śmierci najemnika winnego morderstwa), czym naraża się całej rodzinie. W kontekście kulturowym ówczesnej Grecji Eutyfron znajduje się w konflikcie wartości i zobowiązań o religijnym charakterze. Na jednej szali leży cześć i lojalność wobec ojca, na drugiej wymóg wymierzenia sprawiedliwości dla zabójcy. Dlatego właśnie Sokrates pyta młodego rozmówcę: „Na Boga, Eutyfronie! Czy myślisz, że twoja wiedza spraw boskich, rzeczy zbożnych i bezbożnych jest tak wielka, że przy tym stanie rzeczy nie boisz się, skarżąc własnego ojca, popełnić bezbożności?" [4e]. Odpowiedź brzmi niezwykle pewnie: „Eutyfron niczym by się nie różnił od tłumu, gdyby nie znał ściśle tego wszystkiego" [5a].

48 Por. Nussbaum, The Therapy of Desire. Theory and Practice in Hellenistic Ethics, $16-21$.

${ }^{49}$ Cytaty z tego dialogu podaję według wydania Platon, Eutyfron, przeł. Józef Bocheński (Warszawa: Fundacja Augusta hr. Cieszkowskiego, 2015). Dla uproszczenia nie podaję $\mathrm{w}$ przypisach stron, lecz $\mathrm{w}$ kwadratowych nawiasach umieszczonych w tekście głównym uniwersalną numerację dzieł Platona. 
Pewny swej wiedzy dotyczącej spraw boskich młody rozmówca Sokratesa uzasadnia swoje postępowania poprzez odwołanie się do mitologicznych historii konfliktów pomiędzy bogami. Wskazuje, że działa analogicznie do Zeusa, który ukarał swego ojca, Kronosa, za pożeranie własnych dzieci. By analogia mogła pełnić rolę, w której ją obsadza wieszczek, mit musi być rozumiany dosłownie. I do takiej jego interpretacji Eutyfron się przyznaje. Sokrates jednak za pomocą serii pytań prowadzi rozmówcę do rozpoznania, że uznanie rzeczywistego konfliktu w świecie bogów uniemożliwia takie pojmowanie zbożności, jakie Eutyfron dotąd posiadał. Dalsze pytania Sokratesa doprowadzają rozmówcę do odkrycia, że każda próba określenia, czym jest zbożność, zmusza go do odrzucenia jakiegoś innego fragmentu swojego dotychczasowego religijnego obrazu świata. Eutyfron zrezygnowany stwierdza: „Nie wiem doprawdy, Sokratesie, jak wypowiedzieć, co mam na myśli. Bo cokolwiek wysuniemy, to zaraz przechodzi jakoś i nie chce stać, gdzieśmy je postawili" [11b].

Pomimo że dialog toczy się dalej powyższe zdanie dobrze podsumowuje efekt terapii zastosowanej przez Sokratesa: wytrąca ona religijne myślenie rozmówcy ze stanu fundamentalistycznej katatonii i wprawia je w ruch. Co jeszcze ważniejsze, rozmowa z Sokratesem wprawia w ruch nie tylko myślenie Eutyfrona, ale i jego samego. Gdy rozmówca filozofa orientuje się, że nie wie nic z tego, co mu się wydawało, że wie, i że musi budować swój religijny światopogląd od początku, przerywa rozmowę słowami: „czas mi odejśćc i - jak możemy się domyślić ze słów Sokratesa - ucieka.

Takie zakończenie dialogu jest tylko pozorną porażką filozofa. Jemu wszak nie chodzi o to, by Eutyfron zamienił jeden statyczny system religijnych przekonań na inny (choćby bardziej dogłębnie przemyślany). Celem rozmowy jest zmiana $\mathrm{w}$ duszy rozmówcy. Przecież w Uczcie zostaliśmy pouczeni, że pragnieniem erosa-filozofa jest poczęcie i zrodzenie człowieka w pięknie. To właśnie w tym celu filozof postępuje drogą poznania samego siebie wskazaną przez boga Apolla każdemu przychodzącemu do wyroczni. Dialog Sokratesa z Eutyfronem zmierza nie tylko do rozpoznania problemów cechujących tradycję religijna, ale przede wszystkim do ujawnienia rzeczywistego stanu młodego wróżbity. W trakcie rozmowy zdemaskowania zostaje jego hubris ${ }^{50}$ oraz złudzenia co do własnej osoby, w których tkwi i na których jego hubris się opiera. W tej perspektywie kończąca dialog ucieczka Eutyfrona z portyku króla - czyli rezygnacja (choćby tymczasowa) z oskarżenia ojca - jest jak najbardziej pożądaną zmianą.

50 Jedna z podstawowych wad piętnowanych m.in. w sentencjach mędrców wypisanych w świątyni delfickiej. Por. Bielawski, Delficki trójnóg. Sentencje delfickie. 
Przyglądając się procesowi sokratejskiej terapii, warto zwrócić uwagę także na sposób prowadzenia rozmowy przez filozofa. Powtarza on często frazy w rodzaju: „zabierzmy się do zbadania naszych słów...”, „, co nazywasz...?", , jak pojmujesz...?". Co jakiś czas podsumowuje wywód Eutyfrona w taki sposób, by tamten zgodził się z proponowanym podsumowaniem. Przypomina wcześniejsze ustalenia: „czy nie powiedzieliśmy również...?" i pyta dalej dopiero, gdy uzyska aprobatę rozmówcy. Odnajdując problematyczne miejsca wywodu Eutyfrona (np. definicje, z których płyną niechciane wnioski), proponuje korektę, lecz znowu tak, by rozmówca na tę poprawę się zgodził.

Działanie Sokratesa - stawianie pytań, wskazywanie przykładów, podsumowywanie ujawniające logiczną strukturę wywodu rozmówcy - można określić jako aktywność o wybitnie racjonalnym charakterze. Ma ona na celu pomoc $w$ rozeznaniu się rozmówcy $w$ sposobie, $w$ jaki używa on kluczowych pojęć, w uświadomieniu sobie ukrytych założeń swojego myślenia i działania ${ }^{51}$.

Uważna lektura Eutyfrona wskazuje jednak także, w jakim sensie i w jakim stopniu filozofowi prowadzącemu tak racjonalną terapię potrzebne jest własne religijne zaangażowanie. Otóż wszelkie próby ujęcia zasadniczej kwestii: na czym polega zbożność/pobożność (eusebeia), czyli co jest istotą religijności, opierają się na analogiach z rozmaitymi zjawiskami i działaniami spoza religijnej formy życia. Gdy Eutyfron próbuje określić zbożność jako służbę bogom lub troskę o nich, Sokrates rozjaśnia użyte tu pojęcia służby i troski, wskazując na rozmaite przyziemne przykłady sytuacji (jak choćby hodowla koni), w których analizowane $\mathrm{w}$ rozmowie pojęcia znajdują bezsporne zastosowanie. Kluczową kwestią jest tutaj to, gdzie są granice analogicznego zastosowania wspomnianych terminów w odniesieniu do pytania religijnego. W dialogu nie pojawia się jakaś zewnętrzna, uniwersalna i explicite sformułowana reguła przenoszenia pojęć nie-religijnych w obszar religijnej formy życia. Żaden z rozmówców nie zdradza chęci do sformułowania takiej reguły. Obaj w każdym konkretnym przypadku opierają się na swoim wyczuciu spraw religijnych. Wyraźnie widać to we fragmencie, w którym Sokrates pyta: „Czy zgodziłbyś się, że spełniając jakiś zbożny uczynek, robisz któregoś z bogów lepszym?". Eutyfron odpowiada: „Dalibóg, nie zgadzam się". Sokrates zaś konkluduje: „Ja też nie myślę, że ty tak mówisz - daleko do tego; dlatego właśnie spytałem, co rozumiesz przez »obsługę bogów «, bo nie sądziłem, abyś coś takiego miał na myśli" [13c-d]. Nie ma tu żadnego uzasadnienia, dlaczego Eutyfron

51 Warto tu zauważyć podobieństwo do sposobu filozofowania (późnego) Wittgensteina. 
czegoś nie mógł mieć na myśli. Dla ludzi religijnych pewne kwestie są oczywiste, np. że żadne religijne działanie nie może uczynić obiektów religijnej czci lepszymi. Oczywistość ta bierze się z religijnej intuicji, iż coś, co człowiek może uczynić lepszym przez swoje działanie, nie jest warte religijnej czci. Tego jednak nie da się udowodnić komuś, kto nie posiada doświadczenia praktykowania religijnego kultu i wykształconej przez tę praktykę intuicji. W naszym przypadku rozmówcy mogą się w tym punkcie porozumieć, gdyż obaj posiadają tę intuicję. Porozumienie to zaś jest warunkiem koniecznym zorientowania się, że rozumowanie zabrnęło w ślepą uliczkę i że potrzebny jest ruch dyskursu w innym kierunku.

III

Traktując dialog Sokratesa z Eutyfronem jako wzorzec procesu filozoficznej terapii religii, można pokusić się o dokonanie kilku uogólnień.

Filozof-terapeuta nie tyle wygłasza wykłady i poucza człowieka religijnego ${ }^{52}$, co raczej stawia mu pytania. Pytania filozofa-terapeuty nawiązują zawsze do założeń i przekonań człowieka religijnego. Tak więc, gdy mówimy o filozoficznej terapii religii, ważne jest to, by odnotować, że filozofia nie musi tu wymyślać całego uniwersum symbolicznego, które prowadziłoby człowieka do spełnienia. Wchodząc w dialog z człowiekiem zanurzonym i wychowanym $\mathrm{w}$ danej tradycji religijnej, filozof korzysta z wielu symboli i mitów powstałych w tej tradycji. Stawia pytania o właściwą interpretację tego materiału. Bada jego spójność i to na dwóch płaszczyznach - jako wewnętrzną koherencję przekonań i jako powiązanie tego, co powiedziane i/lub pomyślane, z praktykami i religijnym doświadczeniem. Dąży to tego, by rozmówca zdał sobie sprawę z konsekwencji myśli, które żywi na tematy religijne, religijnych praktyk, które uprawia, i doświadczeń, które w konsekwencji tamtych stają się jego udziałem. Jeśli już nie pyta, lecz wypowiada się w sposób pozytywny, to niczym Wittgenstein z czasów Dociekań podsuwa przed oczy rozmaite sytuacje i możliwe zachowania (zwłaszcza zachowania językowe), jednak nie w celu przedstawienia ogólnej teorii, ale ujawnienia złudzeń i pomocy w zorientowaniu się, „jak się rzeczy mają".

W tak rozumianym procesie filozoficznej terapii filozof wykorzystuje bogate instrumentarium swej dyscypliny, do którego należą: (i) wprowadzanie dystynkcji odnośnie do sposobów używania pojęć albo sposobów funkcjonowania (m.in. żywienia poglądów); (ii) odnajdywanie/rozpoznawanie związków pomiędzy "posunięciami” w danej

${ }^{52} \mathrm{~W}$ idealnej sytuacji mógłby powtórzyć stwierdzenie Sokratesa z Obrony: „Ja nie byłem nigdy niczyim nauczycielem" - Platon, Obrona Sokratesa, przeł. Władysław Witwicki, w: Platon, Dialogi (Gdańsk: Tower Press, 2000), 118. 
grze językowej, tj. pojęciami, aspektami i elementami życia; (iii) projektowanie eksperymentów myślowych, tj. dostarczanie rozmówcy dyskutowalnych obrazów świata i wskazywanie w ten sposób na istnienie innych możliwości myślenia i działania; wreszcie (iv) stawianie pytań, które mają zainspirować i nakierować rozmówcę, by sam doszedł do (i), (ii) i (iii). W tym procesie (iv) jest najważniejsze, lecz w sytuacjach „zastoju" filozof-terapeuta (jak Sokrates) podsuwa (i), (ii) i (iii), by poruszyć proces myślowy rozmówcy; dba przy tym, by rozmówca przyjął (uznał za swoje) podsunięte przez niego dystynkcje i obrazy świata.

Ostatecznie jednak chodzi mu nie tyle o system przekonań, co o samego człowieka i jego sposób życia ${ }^{53}$. Celem jest wprowadzenie człowieka religijnego poddanego terapii $\mathrm{w}$ intelektualny i egzystencjalny ruch.

Na koniec warto zaznaczyć, że filozof-terapeuta wcale nie musi być nieomylnym ekspertem $\mathrm{w}$ kwestiach religijnych. Jako filo-sophos jest wszak tym, który nie wie, mając świadomość, że i dlaczego nie wie. Nie musi być też religijnym herosem lub świętym. Wystarczy, że dąży do egzystencjalnej przemiany (zrodzenia w pięknie) i poznania samego siebie.

Możemy tu zastosować rozróżnienie, które odnośnie do terapii poznawczej wprowadziła jedna z jej głównych teoretyczek - Christinie Padesky. Terapia poznawcza posługuje się techniką zwaną dialogiem sokratejskim (wzorowaną na tym, co możemy wyczytać u Platona). Padesky zwraca uwagę na radykalną różnicę pomiędzy dwoma rodzajami terapii poznawczej: w pierwszym chodzi po prostu o zamianę jednego systemu przekonań pacjenta (niespójnego, nieuzasadnionego i nieadaptacyjnego) na inny; drugi rodzaj terapii ma na celu nauczenie pacjenta właściwej oceny swoich myśli, zachowań, sposobów funkcjonowania, okoliczności życiowych czy reakcji fizjologicznych, tak by był on zdolny do samodzielnych wyborów, które są adaptacyjne ${ }^{54}$. W tym pierwszym modelu terapeuta wie, dokąd zmierza, i pytaniami prowokuje i kieruje pacjenta, by ten też tam doszedł (np. rozpoznał braki w swoim myśleniu, które od początku widzi terapeuta). W drugim modelu terapeuta nie wie, dokąd dojdzie proces terapeutyczny, odkrywa drogę razem $\mathrm{z}$ pacjentem, a raczej swoimi pytaniami pozwala pacjentowi samemu

53 Jak mówił Nikiasz do Lizymacha w dialogu Laches: „,kto się do Sokratesa najbardziej zbliży myślami - jakby krwią - kto do niego blisko podejdzie w rozmowie, ten już musi, choćby o czym innym rozmawiać zaczął, chodzić za nim bez ustanku myślami tam i sam, aż wpadnie i musi zdawać rachunek z siebie samego, jakim trybem teraz żyje i jak minione życie przeżył" - Platon, Laches, 41.

54 Por. Christina A. Padesky, „Socratic Questioning: Changing Minds or Guiding Discovery", Keynote address delivered at the European Congress of Behavioural and Cognitive Therapies, September 1993, London. 
odkrywać drogę i konkretne rozwiązania (i tym samym kształcić w sobie zdolność samodzielnego dostrzegania i rozwiązywania problemów) ${ }^{55}$.

Filozoficzna terapia religii prowadzona w stylu sokratejsko-platońskim ma cechy raczej drugiego z wyżej wymienionych rodzajów. Filozof-terapeuta nie jest wszak mędrcem, lecz tym, który do mądrości dąży. Biorąc zaś pod uwagę powyższe rozważania, można pokusić się też o stwierdzenie, że w zaangażowaniu religijnym nie ma ostatecznych ekspertów, którzy osiągnęliby stan egzystencjalnej doskonałości i nieomylne zrozumienie. Przykład Eutyfrona sugeruje bowiem, że mniemanie, iż ktoś znalazł się na tak wyróżnionej pozycji, jest podstawowym złudzeniem i źródłem religijnych schorzeń i problemów. Jeśli tak, to filozof sam nie może ulec owemu złudzeniu. Ponadto tradycje religijne potrzebują obecności takiego, sokratejsko-erotycznego, filozofa. W innym wypadku grozi im, że zatrzymają się w poznawczym i egzystencjalnym ruchu. Religię pozbawioną takiego ruchu można nazwać fundamentalizmem.

\section{Bibliografia}

Albert Karl. 2002. Wprowadzenie do filozoficznej mistyki, przeł. Jerzy Marzęcki. Kęty: Antyk.

Alkinous. 2008. Wykład nauk Platona (Didaskalikos), przeł. Kazimierz Pawłowski. Kraków: Wydawnictwo WAM.

Banicki Konrad. 2014. „Philosophy as Therapy: Towards a Conceptual Model". Philosophical Papers 43, 1: 7-31.

Banicki Konrad. 2017. „Medyczny model filozofii, czyli między starożytną terapią a współczesną psychologią emocji". W: Therapeia, askesis, meditatio: praktyczny wymiar filozofii o starożytności i średniowieczu, red. Krzysztof Łapiński, Robert Pawlik, Rafał Tichy. Warszawa: Wydawnictwo UW.

Bielawski Krzysztof. 2017. Delficki trójnóg. Sentencje delfickie. Kraków: Wydawnictwo UJ, Lemma Press.

Diogenes Laertios. 2012. Żywoty i poglady stynnych filozofów, przeł. Kazimierz Leśniak. Warszawa: Wydawnictwo Naukowe PWN.

Domański Juliusz. 1996. Metamorfozy pojęcia filozofii, przeł. Zofia Mroczkowska, Mirosław Bujko. Warszawa: Wydawnictwo IFiS PAN.

Epiktet. 1961. Diatryby. Encheiridion, przeł. Leon Joachimowicz. Warszawa: PWN.

Epikur. 2012. Listy oraz wybór świadectw, przeł. Kazimierz Leśniak. Warszawa: Wydawnictwo UKSW.

Gomułka Jakub. 2011. Gramatyka wiary. Dziedzictwo wittgensteinowskiego fideizmu. Kraków: Instytut Myśli Józefa Tischnera.

55 Tamże. 
Fisher Eugen. 2000. Linguistic creativity. Exercises in "Philosophical Therapy". Dordrecht-New York-London: Kluwer Academic Publishers.

Fisher Eugen. 2011. „How to Practice Philosophy as Therapy: Philosophical Therapy and Therapeutic Philosophy". Metaphilosophy 42, 1-2: 49-82.

Hadot Pierre. 2000. Czym jest filozofia starożytna, przeł. Piotr Domański. Warszawa: Aletheia.

Hadot Pierre. 2003. Filozofia jako ćwiczenie duchowe, przeł. Piotr Domański. Warszawa: Aletheia.

Hadot Pierre. 2004. Plotyn albo prostota spojrzenia, przeł. Patrycja Bobowska. Kęty: Antyk.

Kłoczowski Jan A. 2004. Między samotnościa a wspólnota. Tarnów: Biblos.

Marinoff Lou. 2002. Philosophical Practice. San Diego: Academic Press.

Mokrzycki Edmund (red.). 1992. Racjonalność i styl myślenia. Warszawa: Wydawnictwo IFiS PAN.

Nussbaum Martha. 1994. The Therapy of Desire. Theory and Practice in Hellenistic Ethics. Princeton, New Jersey: Princeton University Press.

Padesky Christine A. 1993. „Socratic Questioning: Changing Minds or Guiding Discovery". Keynote address delivered at the European Congress of Behavioural and Cognitive Therapies. September 1993. London.

Pascal Fania. 1984. „Wittgenstein: A Personal Memoir”. W: Recollections of Wittgenstein, red. Rush Rhees. Oxford-New York: Oxford University Press.

Pawłowski Kazimierz. 2007. Misteria i filozofia. Misteryjne oblicze filozofii greckiej. Lublin: Towarzystwo Naukowe KUL.

Pawłowski Krzysztof. 2007. Dyskurs i asceza. Kraków: Wydawnictwo Benedyktynów Tyniec.

Peterman James F. 1992. Philosophy as therapy: an interpretation and defense of Wittgenstein's later philosophical project. New York: State University of New York Press.

Phillips Dewi Z. 1997. „Wiara religijna a gry językowe”, przeł. Michał Szczubiałka. W: Filozofia religii. Fragmenty filozofii analitycznej, 299-322, red. Bohdan Chwedeńczuk, Spacja - Aletheia, Warszawa 1997.

Platon. 1987. Listy, przeł. Maria Maykowska. Warszawa: Wydawnictwo Naukowe PWN.

Platon. 1991. Laches, przeł. Władysław Witwicki. Warszawa: Wydawnictwo Recto.

Platon. 1993. Fajdros, przeł. Leopold Regner. Warszawa: Wydawnictwo Naukowe PWN.

Platon. 2000. Obrona Sokratesa, przeł. Władyslaw Witwicki. W: Platon. Dialogi. Gdańsk: Tower Press.

Platon. 2012. Uczta, przeł. Andrzej Serafin. Warszawa: Sic.

Platon. 2015. Eutyfron, przeł. Józef Bocheński. Warszawa: Fundacja Augusta hr. Cieszkowskiego.

Porfiriusz z Tyru. 2006. List do Marcelli, przeł. Piotr Ashwin-Siejkowski. Kraków: Wydawnictwo WAM. 
Robertson Donald. 2010. The Philosophy of Cognitive-Behavioural Therapy. Stoic Philosophy as Rational and Cognitive Psychotherapy. London: Karnac.

Russell Bertrand. 1974. Letters to Russell, Keynes, and Moore, ed. Georg H. von Wright. Ithaca, New York: Cornell University Press.

Sady Wojciech. 1995. „Wprowadzenie”. W: Ludwig Wittgenstein. Uwagi o religii i etyce. 7-57. Kraków: SIW Znak.

Sikora Piotr. 2004. Słowa i zbawienie. Dyskurs religijny w perspektywie filozofii Hilarego Putnama. Kraków: Universitas.

Winch Peter. 1992. „Rozumienie społeczeństwa pierwotnego”, przeł. Tadeusz Szawiel. W: Racjonalność i styl myślenia, red. Edward Mokrzycki. Warszawa: Wydawnictwo IFiS PAN.

Winch Peter. 1995. Idea nauki o społeczeństwie i jej związki z filozofia, przeł. Bohdan Chwedeńczuk. Warszawa: Oficyna Naukowa.

Wittgenstein Ludwig. 1995. Wykłady o wierze, przeł. Wojciech Sady. W: Ludwig Wittgenstein. Uwagi o religii i etyce. Kraków: SIW Znak.

Wittgenstein Ludwig, 2000. Dociekania filozoficzne, przeł. Bogusław Wolniewicz. Warszawa: Wydawnictwo Naukowe PWN.

\section{Streszczenie}

Przedmiotem mojego artykułu jest próba zastosowaniu idei filozofii jako terapii w odniesieniu do religii. Zagadnienie jest o tyle istotne, iż wiele współczesnych form religii posiada cechy, które wydają się dysfunkcyjne - wymagają "terapii". Czy taką terapią może być filozofia?

Istnieją argumenty, że filozofia nie ma kompetencji, by cokolwiek osądzać, a tym bardziej zmieniać w religii. Zarzuty "filozoficzny" głosi, że filozofia i religia to różne, autonomiczne "gry językowe", a każda "gra" posiada sobie właściwe reguły, które nie mogą być osądzane i zmieniane w świetle reguł innej "gry". Zarzut "teologiczny", że religia opiera się na boskim objawieniu i wszelkie czysto ludzkie roszczenia do osądu tego, co pochodzi ze sfery absolutnej, są nieuprawniona, a wręcz bluźnierczą uzurpacją.

W moim tekście chcę pokazać, że (a) istnieje sposób filozofowania, wobec którego powyższe zarzuty są nietrafione oraz (b) zarysować szkic programu „filozoficznej terapii religii".

Słowa kluczowe: filozofia, religia, terapia

\section{Socratic and Platonic Philosophical Therapy of Religion. An Outline of the Issue}

\section{Summary}

In my paper, I try to apply to religion the idea of philosophy as therapy. The issue seems to be an important one - as far as many contemporary forms of re- 
ligion seem to be dysfunctional - i.e. are in need of therapy. Can philosophy be such a therapy?

There are arguments that philosophy has no competence to judge religion, even less - to try to change it. "Philosophical" argument claims that philosophy and religion are autonomous language games; no rule of a given game should be judged under the rules of another game. "Theological" argument states that religion is based on the divine revelation, and any human claim to judge what comes from the divine realm is an unjustified and blasphemous usurpation.

I (a) try to show that there is a way of doing philosophy that can face both of the above arguments and (b) sketch a program of "philosophical therapy of religion".

Keywords: philosophy, religion, therapy 